Genii Ortopedii, Vol. 26, no 4, 2020

(C) Shershneva O.G., Kirpichev I.V., 2020

DOI 10.18019/1028-4427-2020-26-4-593-599

\title{
Modern approaches to the treatment of scapholunate interosseous ligament injuries (literature review)
}

\author{
O.G. Shershneva, I.V. Kirpichev
}

Ivanovo State Medical Academy, Ivanovo, Russian Federation

\begin{abstract}
Purpose The scapholunate interosseous ligament binding the scaphoid and lunate is a primary stabilising ligament between these two bones. The ligament tear causes chronic instability and degenerative arthritis of the wrist. The scapholunate tears are characterized by different degrees of lesions and their remoteness. The paper is a review of various techniques used to repair or reconstruct the scapholunate ligament according to the clinical stages and anatomic-pathologic findings. Methods A review of the literature covering this topic is presented. Results Conservative treatment is primarily indicated in stable and partial ligament tears. Arthroscopic treatment is used when immobilization is unsuccessful. Reduction of scapholunate space and fixation with Kirshner wires are the most frequently used arthroscopic techniques. Primary repairs of the injured ligaments are performed surgically with efficient results. Surgical indications depend on the severity of the instability, the remoteness of the injury and the presence of degenerative changes. Acute repairs of scapholunate ligament injuries is the 'gold standard' as an earlier intervention provides better results. Acute injuries to the scapholunate ligament require twofour weeks before surgery. Within this period the ligament is often still repairable itself both with or without supplementary capsulodesis procedures; ligament reconstruction is generally preferable in patients with chronic injures. There are many arthroscopic techniques to treat chronic scapholunate injures such as scapholunate ligament primary repair using various types of capsulodesis, tendon graft reconstruction, bone-ligament-bone procedure, various intercarpal fusions and proximal row carpectomy, total wrist fusion and arthroplasty. The paper is a review of various techniques used to repair or reconstruct the scapholunate ligament according to the clinical stages and anatomicpathologic findings. Conclusion Early diagnosis and management of scapholunate ligament tears are necessary to preserve wrist functions. Keywords: wrist, scapholunate ligament, scapholunate ligament injury
\end{abstract}

\section{INTRODUCTION}

Diagnosis and treatmentof injuries to thescapholunate ligament (SLL) is a common and well-researched topic in the medical literature of our country and CIS countries [1-6]. SLL injuries are common in young active individuals with high functional demands [7]. When not properly diagnosed and treated, they can lead to SLL instability, functional disabilities and progressive degenerative osteoarthritis, scapholunate advanced collapse, known as SLAC wrist $[4,6,8,9]$. About 16$40 \%$ of SLL injuries can be associated with distal radius fractures [10-14], scaphoid fractures and other wrist injuries $[8,15]$. The scapholunate interosseous ligament is a c-shaped intrinsic ligamentous structure of the wrist stabilizing both the scaphoid and the lunate $[3,7,8,16$ 21]. Dart thrower's motion of the wrist involves wrist extension with radial deviation and wrist flexion with ulnar deviation that minimizes stress to the SLL. The kinematics of the dart is essential for rehabilitation of SLL injury [7, 22, 23]. Diagnosis of SLL injury includes physical examination for tenderness, a Watson scaphoid test [1, 24], radiological evidence of a scapholunate gap of more than 2-4 mm, scapholunate angle $>60^{\circ}$ and cortical ring sign caused by scaphoid malalignment $[3,7,9,19,24-27]$. Early clinical and radiological presentation may be subtle, and pre-dynamic instability can be identified with the use of advanced imaging or intraoperatively. Contrast arthrographic examinations of the wrist offered more than half a century ago have been criticized for having low sensitivity and low specificity [28]. Sonography [29, 30], computed tomography (CT) $[3,31]$, MR imaging of the wrist allow detection of ligament injuries. Many researchers demonstrate advantages of magnetic resonance arthrography (MRA) with contrast-sensitive images [3, 7, 8, 28, 32-35]. Wrist arthroscopy is considered the gold standard for complete evaluation of scapholunate interosseous ligament injury and patterns of injury [7, 9, 21, 24].

\section{Classification}

Literature review revealed multiple classifications for SLL injuries. W.B. Geissler, M. Garsia-Elias et al. developed an arthroscopic-based grading system for SLL instability and clinical considerations. J.C. Messina et al. devised a new classification system of the European Wrist Arthroscopy Society (EWAS) as an evolution of the W.B. Geissler arthroscopic classification describing specific portions of SLL [7, 9, 13, 21, 24]. R. Luchetti et al. offered detailed clinical classification of SLL injuries and specific indications for each type of SLL tear. They classified injuries as occult/pre-dynamic, dynamic, static with possible decrease in scapholunate space, static instability with no decrease in scapholunate space [36]. 


\section{Treatment}

N. Morrell et al (2017) described treatment algorithm for SLL injury (Table 1) [24]. Treatment strategy was shown to be largely dependent on the severity of SLL injury, denegerative arthritis of the wrist and time after injury. In 2017, J. Andersson described acute injuries as those presented within four weeks after the initial trauma and subacute injuries as those presented at four weeks to six months [13]. Chronic injuries were those presented six months after the initial trauma [37]. The therapeutic options are notably reduced in case of chronic lesions thus indicating the importance of primary repair [38, 39]. In general, SLL injuries can be treated nonsurgically (Table 2) and surgically (Table 3 ).

Table 1

Treatment algorithm for SLL injury

\begin{tabular}{|c|l|l|}
\hline$№$ & \multicolumn{1}{|c|}{ Injury pattern } & \multicolumn{1}{c|}{ Treatment strategy } \\
\hline 1 & Partial SLL tear & Immobilization, arthroscopic debridement/pinning \\
\hline 2 & Acute complete injury with reparable SLL & Primary repair (suture) with/without capsulodesis \\
\hline 3 & $\begin{array}{l}\text { Complete injury with irreparable ligament and reducible } \\
\text { scaphoid subluxation }\end{array}$ & $\begin{array}{l}\text { Primary soft tissue repair with or without capsulodesis, } \\
\text { reconstruction (tendon weaves, BRB reconstruction, and } \\
\text { RASL), tenodesis (Brunelli or modifications), SLAM }\end{array}$ \\
\hline 4 & $\begin{array}{l}\text { Complete injury with irreducible scaphoid subluxation and } \\
\text { DISI (dorsal instability of intermediate segment) }\end{array}$ & $\begin{array}{l}\text { Capsular release and reconstruction, proximal row } \\
\text { carpectomy, limited wrist fusion }\end{array}$ \\
\hline 5 & Scapholunate advanced collapse (SLAC) & $\begin{array}{l}\text { Arthroscopic debridement, neurectomy, proximal row } \\
\text { carpectomy, limited wrist fusion }\end{array}$ \\
\hline
\end{tabular}

Table 2

Nonsurgical treatment of SLL injuries

\begin{tabular}{|l|l|l|l|}
\hline \multicolumn{1}{|c|}{ Stage } & \multicolumn{1}{c|}{ Treatments } & \multicolumn{1}{c|}{ Goal } & \multicolumn{1}{c|}{ Result } \\
\hline $\begin{array}{l}\text { Acute (presented within four weeks } \\
\text { of injury) and subacute injuries } \\
\text { (4-6 weeks after trauma) }\end{array}$ & $\begin{array}{l}\text { Immobilization (4-6 weeks) } \\
\text { thrower's motion }\end{array}$ & $\begin{array}{l}\text { Create conditions for ligament } \\
\text { regeneration }\end{array}$ & $\begin{array}{l}\text { Positive result with } \\
\text { early detection of } \\
\text { injury }\end{array}$ \\
\hline $\begin{array}{l}\text { Chronic injuries (more than six } \\
\text { weeks of injury) }\end{array}$ & $\begin{array}{l}\text { Bracing (dynamic and static } \\
\text { orthoses) }\end{array}$ & $\begin{array}{l}\text { Unload the wrist, pain relief, } \\
\text { prophylaxis of contractures }\end{array}$ & Palliative treatment \\
\hline
\end{tabular}

Table 3

Operative treatment of SLL injuries

\begin{tabular}{|c|c|c|c|}
\hline Stage & Treatments & Goal & Results \\
\hline \multirow{3}{*}{$\begin{array}{l}\text { Acute injuries } \\
\text { (presented within } \\
\text { four weeks of } \\
\text { injury) }\end{array}$} & \begin{tabular}{|l|} 
Stabilization of SLL with \\
wires ( $8-10$ weeks)
\end{tabular} & $\begin{array}{l}\text { Create conditions for } \\
\text { ligament regeneration }\end{array}$ & $\begin{array}{l}\text { Positive result with early detection of } \\
\text { injury (J.K. Andersson) [13] }\end{array}$ \\
\hline & $\begin{array}{l}\text { Arthroscopic debridement and } \\
\text { wire fixation }\end{array}$ & $\begin{array}{l}\text { Create conditions for } \\
\text { ligament regeneration }\end{array}$ & $\begin{array}{l}\text { Pain relief, increase in strength and ROM } \\
\text { of the wrist (J.I. Lee et al.) [24] }\end{array}$ \\
\hline & $\begin{array}{l}\text { Arthroscopically assisted open } \\
\text { repair of SLL and capsulodesis }\end{array}$ & $\begin{array}{l}\text { Restoration of ligament } \\
\text { integrity }\end{array}$ & $\begin{array}{l}\text { Flexion contractures (G. Blatt), no } \\
\text { contractures and pain relief (R.M. Szabo } \\
\text { et al.) [9] }\end{array}$ \\
\hline \multirow{7}{*}{$\begin{array}{l}\text { Subacute injuries } \\
\text { (4-6 weeks after } \\
\text { trauma) and chronic } \\
\text { injuries (more than } \\
\text { six weeks of injury) } \\
\text { without arthritis }\end{array}$} & $\begin{array}{l}\text { Arthroscopically assisted } \\
\text { or open tenodesis and } \\
\text { capsulodesis }\end{array}$ & Ligament reconstruction & $\begin{array}{l}\text { Joint contracture - loss of 30-60 \% flexion } \\
\text { (G.A. Brunelli et al.), improved ROM (V. } \\
\text { den Abbeele et al.) [7] }\end{array}$ \\
\hline & Four-ligament tenodesis & Ligament reconstruction & $\begin{array}{l}74 \% \text { patients satistfied with outcome (M. } \\
\text { Garcia-Elias) [7] }\end{array}$ \\
\hline & SLAM & Ligament reconstruction & $\begin{array}{l}\text { Decrease in SLL angle and space, } \\
\text { moderately limited function (J. Yao et al.) } \\
{[40]}\end{array}$ \\
\hline & RASL & Ligament reconstruction & $\begin{array}{l}\text { Loosening of the screw, development of } \\
\text { arthritis (M.P. Rosenwasser) [36] }\end{array}$ \\
\hline & $\begin{array}{l}\text { Bone-ligament-bone graft } \\
\text { harvested from extensor } \\
\text { retinaculum; from 3rd } \\
\text { carpometacarpal joint }\end{array}$ & Ligament reconstruction & $\begin{array}{l}\text { Inconsistent SLL space and angle } \\
\text { (A.Weiss) [7]; strength of 3rd } \\
\text { carpalmetacarpal joint graft is comparable } \\
\text { with that of the SLL (I.J. Harvey) [36] }\end{array}$ \\
\hline & Partial wrist arthrodesis & Wrist joints' fusion & Improved pain at motion $[7,13]$ \\
\hline & Proximal row carpectomy & $\begin{array}{l}\text { Regain motion releiving } \\
\text { pain }\end{array}$ & Improved ROM, pain relief $[7,13]$ \\
\hline \multirow{2}{*}{$\begin{array}{l}\text { Chronic injuries } \\
\text { (more than six } \\
\text { weeks of injury) } \\
\text { with signs of } \\
\text { arthritis }\end{array}$} & Total wrist arthrodesis & $\begin{array}{l}\text { Ankylosis of the wrist } \\
\text { joint }\end{array}$ & $\begin{array}{l}\text { Pain relief, no motion in the wrist ( J.K. } \\
\text { Andersson) [13] }\end{array}$ \\
\hline & Total wrist arthroplasty & Restoration of motion & Motion restored (Jin-Xing Ma) [41] \\
\hline
\end{tabular}


Nonsurgical treatment in acute partial SLL tears includes immobilization during four-to-six weeks with slightly extended wrist [9]. Wrist splint maintaining dart thrower's motion can be used to prevent contractures and restore specific movements of the wrist to ensure everyday activities [22-24, 42-44]. The splint consists of two components: the wrist portion and for the forearm portion closing on the ulnar side (Fig. 1). Two hinges are placed at the wrist at the level of the tubercle of the scaphoid and the fourth metacarpal corresponding to the ulnar edge of the hamatum having two connecting rods attached to the bone. The rods are rigidly fixed to the forearm block on the palmar radial and dorsal ulnar surfaces. The components are manufactured using thermoplastics and can be formatted to suit individual splinting needs. The splinting construct allows for oblique motion of the wrist, wrist extension with radial deviation and wrist flexion with ulnar deviation that minimizes stress to the SLL.
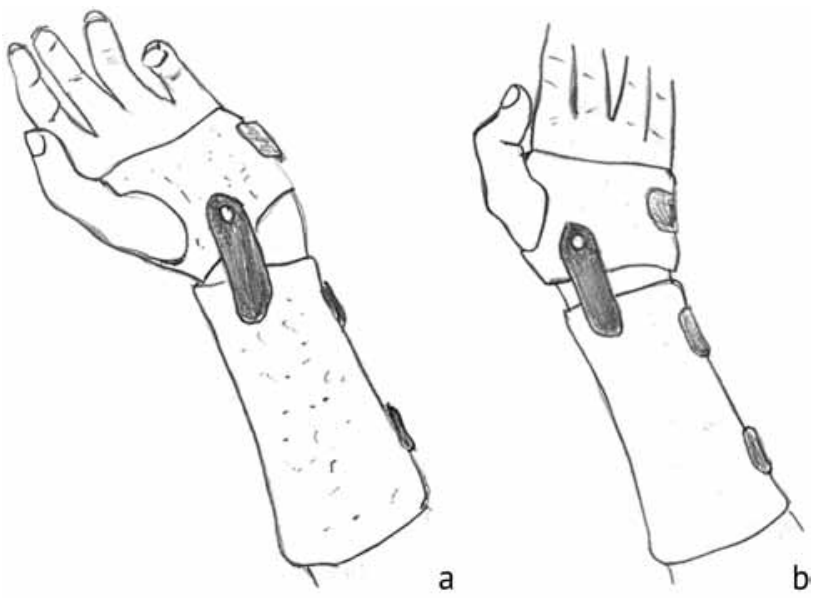

Fig. 1 The splint maintaining dart thrower's motion to allow (a) wrist extension and radial deviation; (b) flexion and ulnar deviation (author's drawing)

Wrist strengthening and proprioceptive exercises are recommended after immobilization [45, 46]. Despite the simplicity of nonsurgical treatment the stage is normally dropped off due to late diagnosis. Although nonsurgical options are available for chronic wrist conditions to unload and prevent joint contractures using static and dynamic orthoses [47] the treatment is palliative.

In 2015, V.M. Jones showed that acute ligamentous injuries incidentally associated with distal radius fractures could be indirectly treated with immobilization [11]. S. Ioshida et al. recommended scapholunate temporary fixation for ligament injuries combined with distal radius fractures reporting an improvement in the Mayo wrist score with pinning [48]. Many authors advocate k-wire fixation for eight to ten weeks in case of acute isolated partial tear of the SLL to be followed by wrist immobilization $[13,36]$. Early diagnosis of scapholunate injury is mandatory for establishing the prognosis of the injury, Surgical options for the treatment of SLL injuries include both open and arthroscopic procedures and can be broadly classified into limited arthroscopic procedures, primary ligament repair, reconstructive procedures and salvage procedures [49]. Limited arthroscopic procedures include ligament debridement and fixation of the SLL space with wires. The technique can be applicable to acute and partial SLL injuries with improved pain and grip strength. M. Pirolo et al. reported thermal radiofrequency treatment of the ligament resulting in denervation [24]. N.A. Darlis et al. reported full range of motion and $78 \%$ of the wrist strength recovered in 14 out of 16 patients at a 19-month follow-up after thermal radiofrequency treatment [7]. I. Pappou et al. reported satisfactory outcomes of anatomical repair for acute injuries and inferior results in chronic cases [7]. Acute injuries of the SLL can be repaired with the arthroscopic technique using bone anchors or by open surgery with capsulotomy $[9,20]$. V. Garratala et al. showed the advantage of the arthroscopic technique over open procedure for SLL repair with bone anchors and capsulodesis avoiding injuries to the periarticular soft tissue and the posterior interosseous nerve [20]. B. Bickert et al. reported $66 \%$ good and excellent results with the use of bone anchors [7]. Different types of dorsal capsulodesis and k-wire fixation can be added to ligament repair [7, 24, 36]. Capsulodesis was first described in 1987 by G. Blatt to stabilize a distal ulna by tethering the scaphoid with a portion of the radioscaphoid capsule in order to hold the scaphoid extended. The procedure also resulted in severe flexion contracture and decreased ROM. Modifications of capsulodesis without fixation to the radius were described by R.M. Szabo et al., R.A. Berger et al. [9] and were helpful to prevent evident postoperative contracture and pain. Radiological signs of instability improved [7]. J.K. Andersson reported capsulodesis as an additional surgical procedure [13].

Chronic SLL injuries cannot be repaired with bone anchors. Different reconstructive techniques of tenodesis and capsulodesis can be used for the case $[49,50]$. Classical tenodesis using the flexor carpi radialis was described by G.A. Brunelli and G.R. Brunelli in 1995 with a mild loss of wrist flexion as a tradeoff, like with the Blatt's capsulodesis using the flap attached to the distal radius. The authors reported postoperative wrist flexion being 
reduced by $30-60 \%$ [7], and the technique of tenodesis underwent multiple modifications [24]. V. den Abbeele et al. and M. Garcia-Elias et al. modified the technique to prevent injury to the radiocarpal joint [7, 36]. V. den Abbeele et al. reported much better outcomes as compared to those from original technique developed by G.A. Brunelli and G.R. Brunelli [7]. M. Garcia-Elias suggested the use of three-ligament tenodesis to restore the sapho-trapezio-trapezoid joint, dorsal scaphoidsemilunar ligament and the dorsal radio-triquetral ligament $[9,13]$ and $74 \%$ reported satisfaction with the treatment [7]. In 2014, A. Elsaftawy et al. used cadaveric samples [37], and A.I. Volotovsky, in 2015 , used patients to modify techniques for placing free tendon grafts in the scaphoid and the semilunar. A.I.Volotovsky reported two-fold improvement of the Mayo wrist score in the patients as compared to baseline [51]. P. De Carly et al. reveiwed 20 patients who underwent tenodesis and capsulodesis at 67 months and reported superior outcomes as compared to those reported by M. Garcia-Elias et al. who used tenodesis alone [52].

Many authors describe reconstruction of the scaphoid-lunar articulation with the use of a short palmaris longus autologous graft between the scaphoid and the lunar along the central rotation axis to maximally approximate the bones and fix them with a wire. The technique is termed as Scapho Lunate Axis Method (SLAM). The wrist is immobilized postoperatively for two weeks with wires removed after six weeks and dart thrower's motion initiated after 10-12 weeks. J. Yao et al. reported decrease in the scapholunate gap from $5.4 \mathrm{~mm}$ to $2.1 \mathrm{~mm}$, the scapholunate angle from 70 degrees to 59 degrees, moderate limitation of the grip strength and wrist function [24, 51]. T. Alonso-Rasgado et al. (2017) compared different tenodesis techniques using cadaveric samples and found that the scapholunate interval showed better improvement with SLAM with volar component involved as compared to G.A. Brunelli and G.R.Brunelli tenodesis [53]. $\mathrm{M}$. Ross et al. took the best features of previously described techniques and offered SL reconstruction utilizing a flap rerouted via transosseous tunnels across the scaphoid, lunate, and triquetrum to simultaneously reconstruct the scapholunar abd lunar-triquetrum ligaments [24, 54]. V. Garratala et al. reported advantages of arthroscopically assisted scapholunar reconstruction with autograft to control the graft passing through the dorsal scapholunar ligament with less invasive approach [20]. In 2015, G.I. Bain et al. reported the cable augmented, quad ligament scapholunate ligament reconstruction using tensionable suture anchors, capsuloplasty and the Berger flap in dynamic instability [55]. M.P. Rosenwasser et al. suggested using cannulated compression screw for the reduction and association of the scaphoid and lunate (RASL) [24, 56]. However, the outcomes of the procedure were not very successful due to loosening of screws over time, destruction of the scaphoid and the lunate and development of arthrosis with the need of screw removal after several months. J.L. Cognet et al. concluded the method should never be employed [36].

SLLstabilitycanbeensured withSLLreconstruction using bone-ligament-bone graft. A. Weiss suggested harvesting graft from Lester's tubercle of the radius using a portion of extensor retinaculum. The author obtained very contradictory results with a wide range of the SL angle (45-87 degrees) and SL interval (3$11 \mathrm{~mm})$. The retinaculum was anatomically weaker than the SLL. I.J. Harvey suggested the use of the third carpometacarpal graft. The graft was secured to the SL with mini screws and anchors [7, 24, 36, 39]. There is no evidence supporting clinical role of vascularized bone grafts [7]. Soft tissue release, scars mobilization can be recommended for chronic SLL injuries with no possibility to decrease SL interval with intact cartilage of the wrist joint to convert the deformity into reducible. SLL reconstruction cannot be considered in the case and a wide range of salvage procedures are available for patients with advanced wrist arthritis. Surgical options include wrist denervation, limited carpal fusions (sapho-trapezio-trapezoid, radioscaphocapitate, radioscapholunate, four-corner), proximal row carpectomy. J.K. Andersson showed similar outcomes of the proximal row carpectomy and limited carpal fusions [7, 13]. Prerequisites for the standard proximal row carpectomy are good cartilage in the lunate fossa of radius and on the proximal pole of capitate that starts articulating with the radius postsurgery [57]. Proximal row carpectomy can be an an effective form of treatment for late-stage arthritis of the wrist if combined with dorsal capsular interposition arthroplasty [58]. Total arthroplasty and total wrist arthrodesis are surgical options for patients with advanced wrist SLAC arthritis [13, 58, 59]. Total wrist arthrodesis provides reliable pain relief and stability, improves pain and quality of life with loss of flexibility and motion with a fused joint if no joint-sparing treatment can be offered [4]. 


\section{CONCLUSION}

Literature review shows that the treatment of scapholunate ligament injuries is controversial. Treatment technique would depend on many factors including injury pattern, the time after injury, diagnosis of ligament injury and experience of the surgeon. Nonsurgical treatment consists of immobilization and functional bracing that ensures good results in acute and limited injury. However, early clinical and radiological presentation may be subtle, and instability can be identified with the use of advanced imaging modalities (MRI, arthroscopy of the wrist) that are not common in detection of wrist injuries in Russia. So, simple and easy access nonsurgical techniques are likely to fall out of treatment armamentarium as well as such less invasive technique as arthroscopic debridement of the ligament has limited use. Suture anchor repair of SLL injury arthroscopically or with arthrotomy has evolved to one of first-line mainstream treatment. Arthroscopically assisted suture allows protection of the wrist soft tissues and the dorsal interosseous nerve. There have been numerous surgical techniques and modifications proposed for treatment of chronic SLL injuries considering condition of the articular cartilage of the wrist having poorer prognosis as compared to acute ligament injury. Different types of tenodesis, capsulodesis, ligament plasty using bone-implantbone graft, proximal row carpectomy, limited wrist fusion with the possibility of arthroscopic procedures have been employed for SLL reconstruction with intact cartilage. Total arthroplasty and total wrist fusion are recommended for cases with lost cartilage. Therefore, creation of algorithm for early detection of SLL injury is the key to successful treatment of SLL injury using simple and easy access nonsurgical and arthroscopic procedures.

\section{Conflict of Interest Statement The authors declare that they have no conflict of interest. Disclosure The authors have received no funding.}

\section{REFERENCES}

1. Golubev I.O. Khirurgiia kisti: karpalnaia nestabilnost [Hand surgery: carpal instability]. Izbrannye Voprosy Plasticheskoi Khirurgii, 2001, vol. 8, no. 1, pp. 1-52. (in Russian)

2. Volotovskii A.I. Diagnostika i lechenie povrezhdenii ladevidno-polulunnogo sochleneniia zapiastia [Diagnosing and treatment of injuries of the wrist scapholunate joint]. Meditsinskii Zhurnal, 2009, no. 1, pp. 37-40. (in Russian)

3. Kadubovskaia E.A. Sovremennye vozmozhnosti luchevoi diagnostiki povrezhdenii sviazok oblasti luchezapiastnogo sustava (obzor literatury) [Current scopes of radiation diagnosis of the ligament injuries in the zone of the radiocarpal joint (Review of the literature)]. Travmatologiia i Ortopediia Rossii, 2010, no. 4 (58), pp. 93-101. (in Russian)

4. Dekailo V.P., Tolstik A.N. Reabilitatsiia patsientov s progressiruiushchim ladevidno-polulunnym kollapsom zapiastia [Rehabilitation of patients with progressing scapholunate collapse of the wrist]. Novosti Khirurgii, 2012, no. 1, pp. 85-88. (in Russian) Available at: http://elib.vsmu.by/handle/123/4843 (accessed 22.06.2019).

5. Sharmazanova E.P. Luchevaia diagnostika nestabilnosti luchezapiastnogo sustava [Radiation diagnosing the radiocarpal joint instability]. Radiologichnii Visnik, 2016, no. 3-4. (60-61), pp. 15-19. (in Russian) Available at: https://docplayer.ru/69555285Luchevaya-diagnostika-nestabilnosti-luchezapyastnogo-sustava.html (accessed 22.06.2019).

6. Volotovskii A.I. Adaptivnyi kollaps zapiastia: differentsirovannyi podkhod k khirurgicheskomu lecheniiu [Adaptive wrist collapse: a differentiated approach to surgical treatment]. Meditsinskii Zhurnal, 2012, no. 3 (41), pp. 21-26. (in Russian)

7. Pappou I.P., Basel J., Deal D.N. Scapholunate ligament injuries: a review of current concepts. Hand (N Y), 2013, vol. 8, no. 2, pp. 146-156. DOI: $10.1007 / \mathrm{s} 11552-013-9499-4$

8. Pahwa S., Srivastava D.N., Sharma R., Gamanagatti S., Kotwal P.P., Sharma V. Comparison of conventional MRI and MR arthrography in the evaluation of wrist ligament tears: A preliminary experience. Indian J. Radiol. Imaging, 2014, vol. 24, no. 3, pp. 259-267. DOI: 10.4103/0971-3026.137038

9. Mathoulin C. Treatment of dynamic scapholunate instability dissociation: Contribution of arthroscopy. Hand Surg. Rehabil., 2016, vol. 35, no. 6, pp. 377-392. DOI: 10.1016/j.hansur.2016.09.002

10.Kwon B.C., Choi S.J., Song S.Y., Baek S.H., Baek G.H. Modified carpal stretch test as a screening test for detection of scapholunate interosseous ligament injuries associated with distal radial fractures. J. Bone Joint Surg. Am., 2011, vol. 93, no. 9, pp. 855-862. DOI: $10.2106 /$ jbjs.j.00361

11.Jones V.M., Everding N.G., Desmarais J.M., Soong M.C. Scapholunate instability after distal radius volar plating. Hand (N Y), 2015, vol. 10, no. 4, pp. 678-682. DOI: 10.1007/s11552-015-9779-2

12.Gajdoš R., Pilný J., Pokorná A. Injury to the Scapholunate Ligament in Distal Radius Fractures: Peri-Operative Diagnosis and Treatment Results. Acta Chir. Orthop. Traumatol. Cech., 2016, vol. 83, no. 5, pp. 336-343. Available at: https://www.ncbi.nlm.nih. gov/pubmed/28102809 (accessed 22.06.2019).

13.Andersson J.K. Treatment of scapholunate ligament injury: Current concepts. EFORT Open Rev., 2017, vol. 2, no. 9, pp. $382-393$. DOI: $10.1302 / 2058-5241.2 .170016$

14.Desai M.J., Kamal R.N., Richard M.J. Management of Intercarpal Ligament Injuries Associated with Distal Radius Fractures. Hand Clin., 2015, vol. 31, no. 3, pp. 409-416. DOI: 10.1016/j.hcl.2015.04.009

15.Shah C.M., Stern P.J. Scapholunate advanced collapse (SLAC) and scaphoid nonunion advanced collapse (SNAC) wrist arthritis. Curr. Rev. Musculoskelet. Med., 2013, vol. 6, no. 1, pp. 9-17. DOI: 10.1007/s12178-012-9149-4

16.Rajan P.V., Day C.S. Scapholunate Interosseous Ligament Anatomy and Biomechanics. J. Hand Surg. Am., 2015, vol. 40, no. 8, pp. 1692-1702. DOI: 10.1016/j.jhsa.2015.03.032 
17.Kapandzhi A.I. Fiziologiia sustavov: skhemy mekhaniki cheloveka s kommentariiami [Joint Physiology: schemes of human mechanics with comments]. In 3 Vol. Verkhniaia konechnost. T. 1 [Upper Limb. Vol. 1]. 6th Ed. M., Eksmo, 2014, pp. 190-240. (in Russian)

18.Patterson R.M., Yazaki N., Andersen C.R., Viegas S.F. Prediction of ligament length and carpal bone diastasis during wrist flexionextension and after simulated scapholunate instability. J. Hand Surg. Am., 2013, vol. 38, no. 3, pp. 509-518. DOI: 10.1016/j. jhsa.2012.12.001

19.Tischler B.T., Diaz L.E., Murakami A.M., Roemer F.W., Goud A.R., Arndt W.F. 3rd, Guermazi A. Scapholunate advanced collapse: a pictorial review. Insights Imaging, 2014, vol. 5, no. 4, pp. 407-417. DOI: 10.1007/s13244-014-0337-1

20.Carratalá V., Lucas F.J., Miranda I., Sánchez Alepuz E., González Jofré C. Arthroscopic Scapholunate Capsuloligamentous Repair: Suture With Dorsal Capsular Reinforcement for Scapholunate Ligament Lesion. Arthrosc. Tech., 2017, vol. 6, no. 1, pp. e113-e120. DOI: $10.1016 /$ j.eats.2016.09.009

21.Geissler W.B. Arthroscopic management of scapholunate instability. J. Wrist Surg., 2013, vol. 2, no. 2, pp. 129-135. DOI: 10.1055/s$0033-1343354$

22.Hillstrom H.J., Garg R., Kraszewski A., Lenhoff M., Carter T., Backus S.I., Wolff A., Syrkin G., Cheng R., Wolfe S.W. Development of an anatomical wrist joint coordinate system to quantify motion during functional tasks. J. Appl. Biomech., 2014, vol. 30, no. 4, pp. 586-593. DOI: org/10.1123/jab.2011-0094

23.Braidotti F., Atzei A., Fairplay T. Dart-Splint: An innovative orthosis that can be integrated into a scapho-lunate and palmar midcarpal instability re-education protocol. J. Hand Ther., 2015, vol. 28, no. 3, pp. 329-334. DOI: 10.1016/j.jht.2015.01.007

24.Morrell N.T., Moyer A., Quinlan N., Shafritz A.B. Scapholunate and perilunate injuries in the athlete. Curr. Rev. Musculoskelet. Med., 2017, vol. 10, no. 1, pp. 45-52. DOI: 10.1007/s12178-017-9383-x

25.Conaghan P.G., O'Connor P.J., Isenberg D.A., eds. Musculoskeletal Imaging. Oxford Specialist Handbooks in Radiology. $1^{\text {st }}$ Ed. Oxford University Press, 2010, 480 p. (Russ. ed.: Konagan F.G., O'Konnor F.Dzh., Izenberg D.M., eds. Luchevaia diagnostika zabolevanii kostno-myshechnoi sistemy: spetsializirovannoe Oksfordskoe rukovodstvo po rentgenologii. M., Izd-vo Panfilova, BINOM, 2014, 464 p.).

26.Dornberger J.E., Rademacher G., Mutze S., Eisenschenk A., Stengel D. Accuracy of simple plain radiographic signs and measures to diagnose acute scapholunate ligament injuries of the wrist. Eur. Radiol., 2015, vol. 25, no. 12, pp. 3488-3498. DOI: 10.1007/ s00330-015-3776-2

27.Gradl G., Neuhaus V., Fuchsberger T., Guitton T.G., Prommersberger K.J., Ring D.; Science of Variation Group. Radiographic diagnosis of scapholunate dissociation among intra-articular fractures of the distal radius: interobserver reliability. J. Hand Surg. Am., 2013, vol. 38, no. 9, pp. 1685-1690. DOI: 10.1016/j.jhsa.2013.05.039

28.Maizlin Z.V., Brown J.A., Clement J.J., Grebenyuk J., Fenton D.M., Smith D.E., Jacobson J.A. MR arthrography of the wrist: controversies and concepts. Hand (N Y), 2009, vol. 4, no. 1, pp. 66-73. DOI: 10.1007/s11552-008-9149-4

29. Jacobson J.A., Oh E., Propeck T., Jebson P.J., Jamadar D.A., Hayes C.W. Sonography of the scapholunate ligament in four cadaveric wrists: correlation with MR arthrography and anatomy. AJR Am. J. Roentgenol., 2002, vol. 179, no. 2, pp. 523-527. DOI:10.2214/ajr.179.2.1790523

30.Gitto S., Messina C., Mauri G., Aliprandi A., Sardanelli F., Sconfienza L.M. Dynamic high-resolution ultrasound of intrinsic and extrinsic ligaments of the wrist: How to make it simple. Eur. J. Radiol., 2017, vol. 87, pp. 20-35. DOI: 10.1016/j.ejrad.2016.12.002

31.Leng S., Zhao K., Qu M., An K.N., Berger R., McCollough C.H. Dynamic CT technique for assessment of wrist joint instabilities. Med. Phys., 2011, vol. 38, no. Suppl. 1, pp. S50. DOI: 10.1118/1.3577759

32.LiMarzi G.M., O’Dell M.C., Scherer K., Pettis C., Wasyliw C.W., Bancroft L.W. Magnetic Resonance Arthrography of the Wrist and Elbow. Magn. Reson. Imaging Clin. N. Am., 2015, vol. 23, no. 3, pp. 441-455. DOI:10.1016/j.mric.2015.04.003

33.Štouračová A., Šprláková-Puková A., Čižmář I., Procházková J., Janoušová E., Vališ P. High-Resolution MR Examination of the Scapholunate Ligament using a Microscopic Coil: Comparison with Direct MR Arthrography and Arthroscopy Findings. Acta Chir. Orthop. Traumatol. Cech., 2016, vol. 83, no. 5, pp. 327-331. Available at: https://pdfs.semanticscholar.org/d8d5/ dcfe313f668e2dc4dc4f. (accessed 22.06.2019)

34.Bille B., Harley B., Cohen H. A comparison of CT arthrography of the wrist to findings during wrist arthroscopy. J. Hand Surg. Am., 2007, vol. 32, no. 6, pp. 834-841. DOI: https://doi.org/10.1016/i.ihsa.2007.04.005

35.Andreisek G., Duc S.R., Froehlich J.M., Hodler J., Weishaupt D. MR arthrography of the shoulder, hip, and wrist: evaluation of contrast dynamics and image quality with increasing injection-to-imaging time. AJR Am. J. Roentgenol., 2007, vol. 188, no. 4, pp. 1081-1088. Available at: https://www.ajronline.org/doi/10.2214/AJR.06.0719 (accessed 22.06.2019).

36.Luchetti R., Atzei A., Cozzolino R., Fairplay T. Current role of open reconstruction of the scapholunate ligament. J. Wrist Surg., 2013, vol. 2, no. 2, pp. 116-125. DOI: 10.1055/s-0033-1343092

37.Elsaftawy A., Jabłecki J., Jurek T., Domanasiewicz A., Gworys B. New concept of scapholunate dissociation treatment and novel modification of Brunelli procedure - anatomical study. BMC Musculoskelet. Disord., 2014, vol. 15, pp. 172. DOI: 10.1186/14712474-15-172

38.Papaloïzos M. Scapholunate lesions and instabilities - how to recognize and treat them? Rev. Med. Suisse, 2015, vol. 11, no. 477, pp. 1251-1256. DOI: org/10. 1024/0040-5930/a000527

39.Petersen W., Rothenberger J., Schaller H.E., Rahmanian-Schwarz A., Held M. Experiences with osteoligamentoplasty according to Weiss for the treatment of scapholunate dissociation. J. Invest. Surg., 2018, vol. 31, no. 4, pp. 313-320. DOI:10.1080/08941939.2017.1330907

40.Yao J., Zlotolow D.A., Lee S.K. ScaphoLunate Axis Method. J. Wrist Surg., 2016, vol. 5, no. 1, pp. 59-66. DOI: 10.1055/s-00351570744

41.Ma J.X., Xu Y.Q. The instability of wrist joint and total wrist replacement. Chin. J. Traumatol., 2016, vol. 19, no. 1, pp. 49-51. DOI: $10.1016 /$ j.cjtee.2015.12.003

42.Feehan L., Fraser T. Early controlled mobilization using dart-throwing motion with a twist for the conservative management of an intra-articular distal radius fracture and scapholunate ligament injury: A case report. J. Hand Ther., 2016, vol. 29, no. 2, pp.191-198. DOI: $10.1016 /$ j.jht.2016.02.012

43.Garcia-Elias M., Alomar Serrallach X., Monill Serra J. Dart-throwing motion in patients with scapholunate instability: a dynamic fourdimensional computed tomography study. J. Hand Surg. Eur. Vol., 2014, vol. 39, no. 4, pp. 346-352. DOI:10.1177/1753193413484630

44.Anderson H., Hoy G. Orthotic intervention incorporating the dart-thrower's motion as part of conservative management guidelines for treatment of scapholunate injury. J. Hand Ther., 2016, vol. 29, no. 2, pp. 199-204. DOI:10.1016/j.jht.2016.02.007

45.Hincapie O.L., Elkins J.S., Vasquez-Welsh L. Proprioception retraining for a patient with chronic wrist pain secondary to ligament injury with no structural instability. J. Hand Ther., 2016, vol. 29, no. 2, pp. 183-190. DOI: 10.1016/j.jht.2016.03.008

46.Wolff A.L., Wolfe S.W. Rehabilitation for scapholunate injury: Application of scientific and clinical evidence to practice. J. Hand Ther., 2016, vol. 29, no. 2, pp. 146-153. DOI: 10.1016/j.jht.2019.03.010 
47.Warwick D., Dunn R., Melikyan E., Vadher J. Hand Surgery. Oxford Specialist Handbooks in Surgery. $1^{\text {st }}$ Ed. Oxford University Press, 2009, 660 p. (Russ. ed.: Uorik D., Dann R., Melikian E., Veder D. Khirurgiia kisti: spetsializirovannoe Oksfordskoe rukovodstvo po khirurgii. M., Izd-vo Panfilova, BINOM, 2013, 704 p.).

48. Yoshida S., Yoshida K., Sakai K., Nakama K., Shiba N. Frequency of Scapholunate Ligament Inguries Associated with Distal Radius Shearing Fracture: Correlation of Fracture Patterns and Ligament Tear. Hand Surg., 2015, vol. 20, no. 3, pp. 440-446. DOI: $10.1142 / \mathrm{S} 0218810415500379$

49. White N.J., Rollick N.C. Injuries of the Scapholunate Interosseous Ligament: An Update. J. Am. Acad. Orthop. Surg., 2015, vol. 23, no. 11, pp. 691-703. DOI: 10.5435/JAAOS-D-14-00254

50.Gandhi M.J., Knight T.P., Ratcliffe P.J. Scapholunate ligament reconstruction using the palmaris longus tendon and suture anchor fixation in chronic scapholunate instability. Indian J. Orthop., 2016, vol. 50, no. 6, pp. 616-621. DOI: 10.4103/0019-5413.193484

51.Volotovskii A.I. Khirurgicheskoe lechenie dissotsiirovannoi nestabilnosti zapiastia [Surgical treatment of the wrist dissociated instability]. Meditsinskii Zhurnal, 2015, no. 3, pp. 38-42. (in Russian) Available at: http:// bsmu.by/bitstream/handle/BSMU/7154 (accessed 22.06.2019)

52.De Carli P., Donndorff A.G., Torres M.T., Boretto J.G., Gallucci G.L. Combined Tenodesis-Capsulodesis for Scapholunate Instability: Minimum 2-Year Follow-Up. J. Wrist Surg., 2017, vol. 6, no. 1, pp. 11-21. DOI: 10.1055/s-0036-1583304

53.Alonso-Rasgado T., Zhang Q.H., Jimenez-Cruz D., Bailey C., Pinder E., Mandaleson A., Talwalkar S. Evaluation of the performance of three tenodesis techniques for the treatment of scapholunate instability: flexion-extension and radial-ulnar deviation. Med. Biol. Eng. Comput., 2018, vol. 56, no. 6, pp. 1091-1105. DOI: 10.1007/s11517-017-1748-1

54.Ross M., Loveridge J., Cutbush K., Couzens G. Scapholunate ligament reconstruction. J. Wrist Surg., 2013, vol. 2, no. 2, pp. 110115. DOI: $10.1055 / \mathrm{s}-0033-1341962$

55.Bain G.I., Watts A.C., McLean J., Lee Y.C., Eng K. Cable-Augmented, Quad Ligament Tenodesis Scapholunate Reconstruction. J. Wrist Surg., 2015, vol. 4, no. 4, pp. 246-251. DOI: 10.1055/s-0035-1564984

56.Opreanu R.C., Baulch M., Katranji A. Reduction and maintenance of scapholunate dissociation using the TwinFix screw. Eplasty, 2009, vol. 9, pp. e7. Available at: https://pdfs.semanticscholar.org/629b/34902fb583687292 (accessed 23.06.2019)

57.Green D.P., Perreira A.C., Longhofer L.K. Proximal Row Carpectomy. J. Hand Surg. Am., 2015, vol. 40, no. 8, pp. $1672-1676$. DOI: 10.1016/j.jhsa.2015.04.033

58.Gaspar M.P., Pham P.P., Pankiw C.D., Jacoby S.M., Shin E.K., Osterman A.L., Kane P.M. Mid-term outcomes of routine proximal row carpectomy compared with proximal row carpectomy with dorsal capsular interposition arthroplasty for the treatment of late-stage arthropathy of the wrist. Bone Joint J., 2018, vol. 100-B, no. 2, pp. 197-204. DOI: 10.1302/0301-620X.100D2.BJJ-2017-0816.R2

59.Reigstad O., Holm-Glad T., Bolstad B., Grimsgaard C., Thorkildsen R., Røkkum M. Five- to 10-Year Prospective Follow-Up of Wrist Arthroplasty in 56 Nonrheumatoid Patients. J. Hand Surg. Am., 2017, vol. 42, no. 10, pp. 788-796. DOI: 10.1016/j. jhsa.2017.06.097

Received: 07.10.2019

\section{Information about the authors:}

1. Olga G. Shershneva, M.D.,

Ivanovo State Medical Academy, Ivanovo, Russian Federation, Email: elga9411@rambler.ru

2. Ivan V. Kirpichev, M.D., Ph.D., Ivanovo State Medical Academy, Ivanovo, Russian Federation, Email: doc.kirpichev@yandex.ru 